Article

\title{
Development of Allergenicity and Toxicity Assessment Methods for Evaluating Transgenic Sugarcane Overexpressing Sucrose-Phosphate Synthase
}

\author{
Intan Ria Neliana ${ }^{1,2}$, Widhi Dyah Sawitri ${ }^{1,2} \oplus^{\circ}$, Netty Ermawati ${ }^{3}{ }^{\circ}$, Tri Handoyo ${ }^{1,4}$ and \\ Bambang Sugiharto $1,2,5, *$ [D \\ 1 Laboratory of Molecular Biology and Biotechnology, Center for Development of Advanced Science and \\ Technology (CDAST), University of Jember, Jl. Kalimantan No. 37, Kampus Tegalboto, Jember 68121, \\ Indonesia; nelianaintanria@gmail.com (I.R.N.); widhi.pasca@unej.ac.id (W.D.S.); \\ trihandoyo.faperta@unej.ac.id (T.H.) \\ 2 Postgraduate Program in Biotechnology, University of Jember, Jl. Kalimantan No. 37, Kampus Tegalboto, \\ Jember 68121, Indonesia \\ 3 Department of Agricultural Production and Central Laboratory for Biosciences, State Polytechnic of Jember, \\ Jl. Mastrip POBOX 164 Jember, Jember 68101, Indonesia; netty@polije.ac.id \\ 4 Department of Agrotechnology, Faculty of Agriculture, University of Jember, Jl. Kalimantan No. 37, \\ Kampus Tegalboto, Jember 68121, Indonesia \\ 5 Department of Biology, Faculty of Mathematics and Natural Sciences, University of Jember, \\ Jl. Kalimantan No. 37, Kampus Tegalboto, Jember 68121, Indonesia \\ * Correspondence: sugiharto.fmipa@unej.ac.id; Tel.: +62-331-321825
}

Received: 26 November 2018; Accepted: 2 January 2019; Published: 8 January 2019

\begin{abstract}
Sugarcane is considered as an industrial crop that produces sugar. The number of transgenic sugarcane on the market is currently increasing. Therefore, investigation of the potential allergens and toxics in transgenic sugarcane is necessary, since there is less information regarding food safety for human consumption. Bioinformatics and experimental analysis were used for the validation of the allergenic potential of transgenic sugarcane overexpressing sucrose-phosphate synthase (SPS). Bioinformatics analysis showed that SPS has no homology with any known allergenic proteins. However, eight-residues identical contiguous sequence was detected, and further specific assessment is required to confirm the potential of allergenicity. The results of protein stability evaluation showed that SPS gradually decreased at $28^{\circ} \mathrm{C}$ and rapidly inactivated at $60^{\circ} \mathrm{C}$ and $90^{\circ} \mathrm{C}$ by heat treatment. In addition, total protein was degraded by simulated gastric fluids (SGF), and simulated intestine fluid (SIF) assays for one-minute incubation. The level of specific IgE in the transgenic sugarcane and controls also showed no potential risk of allergy. An acute oral toxicity assay was performed by oral gavage of transgenic sugarcane juice in mice. The $\mathrm{LD}_{50}$ for transgenic sugarcane juice was $>25 \mathrm{gr} / \mathrm{kg}$ body weight. We propose a development method for allergenicity and toxicity assessment in transgenic sugarcane.
\end{abstract}

Keywords: sucrose phosphate synthase; transgenic sugarcane; allergenicity; toxicity; safety assessment

\section{Introduction}

In agricultural biotechnology, genetically engineered products have triggered a range of social and ethical concerns. The awareness of how biotechnology products will affect human life has been generated in order to protect consumers. The analysis of food safety should be based on scientific evidence and products should be assessed for eligibility for human consumption. According to 
the guidelines of the World Health Organizationn (WHO) and Food and Agriculture Organization (FAO) [1] in the Codex Alimentarius document, several risk assessments are essential to determine whether transgenic crops are safe or not. There are several reports evaluating transgenic crops, including allergenicity and toxicity analysis [2-4] since the substitution or insertion of genetic material has raised risks the issue in allergenicity.

The first step of allergenicity testing on transgenic crops is to identify potential allergens using bioinformatics methods. The amino acid sequences of target proteins expressed in transgenic products are compared with known allergenic proteins to search for sequence similarity or homology through computational studies $[5,6]$. To prove bioinformatics results, other allergenicity analysis has been carried out by certain experimental conditions, including digestion assay with heat treatment [3], in vitro gastric digestion [2,4], and evaluation of $\operatorname{IgE}[7,8]$. A toxicity study, in parallel with an allergenicity assessment, has also been used to assess potential hazards to human through the acute exposure of genetically engineered products to animal model testing [4].

Sugarcane is a major crop that produces sugar in tropical regions, and transgenic sugarcane has been recently developed for drought stress tolerance [9,10], pest resistance [11,12], virus resistant [13,14], and increased crop yield by introducing a gene for sucrose-phosphate synthase (SPS; EC 2.4.1.14) (under review). Several tests for allergenicity and toxicity have to be evaluated in transgenic sugarcane overexpressing gene SPS, since there is no report for the evaluation in transgenic sugarcane. Although authentic SPS is expressed in sugarcane as well, overexpression of SPS will result in the modification of sucrose biosynthesis in sugarcane and this metabolism exchange must be analyzed.

In the present study, we modified the method that has been previously reported for allergenicity $[3,8,15,16]$ and toxicity $[17,18]$ assessments with biochemical and molecular approach in transgenic sugarcane, particularly transgenic sugarcane overexpressing SPS gene. The allergenicity analysis was primarily conducted by homology searching and comparison with any known protein allergens since the allergenic potential of SPS has not been clearly tested. Evaluation using in vitro methods assessing the degradation of protein in digestive fluids and thermal stability analysis were carried out by immunoblotting and enzymatic activity assays. Furthermore, in vivo testing, through the cross-reaction of transgenic proteins with the IgE response in rats, was performed by enzyme-linked immunosorbent assay (ELISA). Mice were used as a model to conduct acute oral toxicity testing because less test substance was required [19].

\section{Materials and Methods}

\subsection{Plant Materials}

Transgenic sugarcane (Saccharum officinarum L.) overexpressing the full-size SPS gene was developed by the Center for Development of Advanced Science and Technology (CDAST), University of Jember (Jember, Indonesia). The vegetatively propagated third generation of the transgenic and non-transgenic (wild type-WT) sugarcane cultivar Bululawang (BL) were grown in a greenhouse (biosafety containment) for 11 months. Four lines of transgenic sugarcane, SP1, SP2, SP3, and SP4, and WT sugarcane were cultivated in pots containing soil. At six months of age, transgenic sugarcanes were analyzed for in vitro assessments, while at approximately 11 months of age, the plants were harvested for in vivo evaluation such as allergenicity and toxicity assays. After harvesting and observation, the transgenic plants were destroyed.

To verify the transgenic sugarcanes, polymerase chain reaction (PCR) was performed on genomic DNA samples using a pair of primers generating a segment of the neomycin phosphotransferase gene (nptII) as the marker gene. The PCR product was electrophoresis on 1\% gel agarose, stained with ethidium bromide and documented on GelDoc 


\subsection{Animals and Housing}

Fourty BALB/c mice (4 weeks old, 20 males and 20 females) were used for the toxicity assessment, and 12 male Wistar rats (4 weeks old) were used for analysis of allergenicity [20]. The animals were obtained and purchased from the Laboratory of Animal Physiology, Maulana Malik Ibrahim State Islamic University (Malang, Indonesia). All animals were housed at CDAST, University of Jember (Jember, Indonesia) and maintained under the same conditions with a temperature of 23 to $25^{\circ} \mathrm{C}, 45 \%$ to $55 \%$ relative humidity, and a photoperiod of $12 \mathrm{~h}$ light $/ 12 \mathrm{~h}$ dark [21,22]. Following one week of acclimatization, the animals were divided into the two treatment groups. All procedures involving animal treatments were approved by the Ethics Committee of Faculty Medicine, University of Jember (Jember, Indonesia) in November 2017.

\subsection{Allergenicity Assessment}

\subsubsection{Bioinformatics Analysis}

The first evaluation in the allergenicity assessment was to compare the amino acid sequence of SPS with those of allergenic proteins. Based on bioinformatics analysis, the potential allergenicity of the SPS protein can be identified via similarity to any known allergens. The sequence of SPS gene (SoSPS1; gene accession number AB001337 in the GenBank) was obtained from the National Center for Biotechnology Information (NCBI) database $[23,24]$ and further aligned for allergenic potency using AllergenOnline (database http:/ / www.allergenonline.com, version 18B) [3,4,25].

\subsubsection{Heat Stability Treatment}

The SPS protein of transgenic sugarcane was prepared for evaluation of its susceptibility to thermal treatment. Three grams of the transgenic sugarcane leaf was pulverized with liquid $\mathrm{N}_{2}$, and the frozen leaf powder was continouesly ground in three volumes of an extraction buffer [ $50 \mathrm{mM}$ MOPs (pH 7.5), $10 \mathrm{mM} \mathrm{MgCl} 2,1 \mathrm{mM}$ EDTA, $2.5 \mathrm{mM}$ DTT, $1 \mu \mathrm{L}$ PMSF, and 10\% PVPP]. The insoluble fraction was removed by centrifugation at 14,000 rpm (Hitachi CR21GIII, Tokyo, Japan) and a temperature of $4{ }^{\circ} \mathrm{C}$ for $10 \mathrm{~min}$. The soluble protein was subjected to PEG- 6000 fractionation between $6 \%$ and $12 \%$, according to a previous method with appropriate modification [24]. The fractioned protein was diluted in $1 \mathrm{~mL}$ buffer containing $50 \mathrm{mM}$ MOPs (pH 7.5), $10 \mathrm{mM} \mathrm{MgCl} 2,1 \mathrm{mM}$ EDTA, and $2.5 \mathrm{mM}$ DTT. The protein content was further measured by the Bradford method [26], and used for a heat stability assessment.

Approximately $0.1 \mathrm{~mL}$ of the soluble protein, with a concentration of $8.5 \mu \mathrm{g} / \mu \mathrm{L}$, was exposed to various temperature treatments of $28{ }^{\circ} \mathrm{C}, 60{ }^{\circ} \mathrm{C}$, and $90{ }^{\circ} \mathrm{C}$ for intervals of $0,5,10$, and $30 \mathrm{~min}$ incubations. At the time interval, $30 \mu \mathrm{L}$ of the soluble proteins were taken and the heating treatments were stopped by immersion of the sample tube in ice. The treated sample was further analyzed for SPS enzymatic activity using spectrophotometer and expressed as $\mu \mathrm{g}$ sucrose/minute/ $\mu \mathrm{g}$ protein. The proteins profile was monitored by immunoblotting using the specific polyclonal antibody against SPS [24].

\subsubsection{In Vitro Simulated Gastric Fluids (SGF) and Simulated Intestine Fluid (SIF) Assays}

The protein samples were prepared by the method described previously in the preparation for the heat stability assay. For these assays, $100 \mu \mathrm{L}$ of the resulting crude SPS protein was assayed for simulated gastric fluid (SGF) containing $0.32 \%(\mathrm{w} / \mathrm{v}$ ) pepsin (Nacalai tesque, Kyoto, Japan) and $34 \mathrm{mM} \mathrm{NaCl}$ at pH 1.2 [15], and simulated intestinal fluid (SIF) containing $10 \mathrm{mg} / \mathrm{mL}$ trypsin (Nacalai tesque, Kyoto, Japan) in $50 \mathrm{mM} \mathrm{KH}_{2} \mathrm{PO}_{4}$ at $\mathrm{pH} 7.5$ [27]. Before assay, the SGF or SIF mixtures were pre-incubated at $37^{\circ} \mathrm{C}$ for 3 min without the presence of crude SPS protein. The crude SPS protein was added with an equal volume of SGF or SIF (1:1 ratio), and the reaction mixture was subsequently incubated at $37^{\circ} \mathrm{C}$ for periods of $0,1,3,5,10$, and $30 \mathrm{~min}$. The assay was performed in duplicate for each condition. The reaction mixtures of SGF and SIF were terminated by the addition of $200 \mathrm{mM} \mathrm{Na}_{2} \mathrm{CO}_{3}$ 
and heating at $100{ }^{\circ} \mathrm{C}$ for $3 \mathrm{~min}$. The changing of SPS activity levels in the SGF and SIF treatments were monitored by enzymatic activity measurement and sodium dodecyl sulfate polyacrylamide-gel electrophoresis (SDS-PAGE, 10\%) [28], followed by CBB-staining, immunoblotting analysis.

\subsubsection{In Vivo Allergenicity Assay in Rats and Measurement of the Protein-Specific IgE Antibody}

The 11-month-old harvested sugarcane stem was ground and squeezed to collect the juice from internodes number 3 to 8 of the transgenic (SP1) and non-transgenic (WT) sugarcane. The sugarcane juice was kept at $-80^{\circ} \mathrm{C}$ for further allergenicity testing in rats. An 18-gauge stainless steel animal feeding needle was utilized for oral gavage [16] with sugarcane juice doses at $8 \mathrm{~g} / \mathrm{kg}$ of body weight per day. Positive control rats were sensitized with Ovalbumin (OVA; Pharmacia, Uppsala, Sweden) weekly for 14 days, while negative control rats were not treated with either sugarcane juice or OVA. Sensitization of OVA to rats was performed through subcutaneous injection of $1 \mathrm{mg}$ OVA in $1 \mathrm{~mL}$ solution containing $0.9 \% \mathrm{NaCl}$ with $3.5 \mathrm{mg}$ aluminum hydroxide (Sigma Aldrich, St. Louis Missouri, MO, USA) [29].

Blood samples were taken by retro-orbital plexus on days 0,7 , and 14 , and sera were obtained by centrifugation of the coagulated blood samples at $5000 \mathrm{rpm}$ and $4{ }^{\circ} \mathrm{C}$ for $15 \mathrm{~min}$. The coagulation process was conducted through incubation of the blood samples at room temperature for $2 \mathrm{~h}$, and the sera was further stored at $-80^{\circ} \mathrm{C}$ until use. Detection of IgE in each serum sample was performed using a rat IgE ELISA kit (Immunology Consultants Laboratory, Inc., Portland, OR, USA) according to the manufacturer's instructions. ELISA analysis was performed to detect the specificity of IgE binding, and to compare the allergenicity between transgenic sugarcane and controls. The IgE proteins were visualized using 3,3',5,5'-tetramethybenzidine (TMB) and hydrogen peroxide as the substrate of horseradish peroxidase-conjugated goat anti-rat IgE for color development. The developed color was measured at an absorbance of $450 \mathrm{~nm}$ using a microtiter plate reader (SH-1000, Corona Electric Co., Ltd., Tokyo, Japan).

\subsection{Acute Oral Toxicity Assessment}

To evaluate the toxicity of transgenic sugarcane, the sugarcane juice was prepared using a method mentioned in the previous section of allergenicity test. The 40 mice were divided randomly into 4 groups, each group consisted of 10 mice with 5 males and 5 females. The groups were treated according to the sugarcane juice dosage induction; group I is injected at a dose of $0 \mathrm{~g} / \mathrm{kg}$ body weight as a negative control, group II is $6.25 \mathrm{~g} / \mathrm{kg}$ body weight, group III is $12.5 \mathrm{~g} / \mathrm{kg}$ body weight, and group IV is $25 \mathrm{~g} / \mathrm{kg}$ body weight, which is equal to sucrose concentration of $0,0.94,1.88,3.76 \mathrm{~g} /$ body weight, respectively. The sucrose contents were determined according to the assumptions of $15 \%$ sucrose content in sugarcane juice [30]. To substitute the sugarcane juice injection at group I, the mice were administered by oral gavage of $0.5 \% \mathrm{CMC}-\mathrm{Na}$ suspension according to a method previously described [31]. The mice were not fed for $12 \mathrm{~h}$ before treatment induction [21,31]. All mice were observed for signs of toxicity (piloerection, motor activity, vocal tremor, and feces) during $4 \mathrm{~h}$ after treatments and daily for 14 days. The weight of the mice was also recorded daily for 14 days of observation $[17,18]$. On day 14 , the mice were sacrificed via cervical dislocation and dissected to examine the morphological condition of vital organs including the liver, spleen, kidneys, and heart.

\subsection{Statistical Analysis}

Statistical analysis was carried out using the statistical software Statistical Product and Service Solutions (SPSS) version 22 (SPSS Inc., Chicago, IL, USA), and the results were considered as significant differences when $p<0.05$. The statistical analysis was calculated to differentiate the allergenicity and toxicity assessments in response to non-transgenic and transgenic sugarcane consumption. 


\section{Results and Discussion}

\subsection{Bioinformatics Assessment of the Protein SPS Expressed in Transgenic Sugarcane}

Bioinformatics analysis was carried out to determine potential allergen and cross-reactivity between SPS and any known allergen proteins. The possibility of cross-reactivity in transgenic crops can be examined by multiple characteristics of sequence comparisons to known allergens. A match alignment of $>35 \%$ identity, over a segment of 80 amino acids, and a contiguous identical match of eight amino acids have been reported to indicate potential cross-reactivity [32,33]

The full-size protein sequence encoded by the SoSPS1 gene (Figure S1A) was subjected to bioinformatics tools through the FASTA search of AllergenOnline (http:/ / www.allergenonline.org, version 18B), and the sequence comparison of SoSPS1 to allergens was performed. The results demonstrated no more than $35 \%$ shared identity over $\geq 80$ amino acids segments (Figure S1B). Thus, sugarcane SPS is not potentially allergenic since there was no similarity with allergenic proteins in the database.

A search for eight identical contiguous amino acid sequences was also conducted, and a sequence match was detected at the N-terminal region of sugarcane SPS with a shared eight-mer (GGGGGGGG). The obtained result from AllergenOnline showed homology to a chitinase from Zea mays L. (Table 1). These eight-residue identical contiguous sequences of sugarcane SPS share conserved homology residues with other C4 plants SPSs, such as sorghum SPS (gene Accession number EES04111.1 in GenBank) and Zea mays L. SPS (gene accession number P31927.1 in GenBank). Nevertheless, the eight-glycine contiguous sequence of sugarcane SPS has not been shown in C3 plants, such as spinach SPS (gene accession number AAC60545.2 in GenBank) and potato SPS (gene accession number CAA51872.1 in GenBank). Accordingly, the results suggested that the 8-residue contiguous sequence of sugarcane SPS is merely representative characteristic of SPS sequence in C4 plants, and it might be no tendency to allergenicity. Moreover, there is no reports that describe the GGGGGGGG segment acts as an epitope in allergenic reaction.

It is noteworthy that the use of 6 to 8 identical amino acids in allergenicity detection is considered contradictory. Previous studies have reported that comparison of 6 to 8 amino acids might yield a false-positive predictive value $[3,34,35]$. There is no sufficient evidence that a short peptide match reveals clinical cross-reactivity $[35,36]$. Therefore, Codex has been recommended as a way to identify 80-amino-acid sequence matches with a known allergen [5,32,34]. However, several regulatory authorities require the evaluation of eight-amino-acid identity matches with allergens [37]. Consequently, scientifically validated testing with specific assessments is required to confirm the allergenicity of overexpressed SoSPS1 in sugarcane. Evaluation of serum IgE testing and in vitro digestibility have been recommended by the Codex Alimentarius Commission guidelines as a further step in allergenicity assessment $[5,34,37]$.

Table 1. Sequence homology of selected sequences using contiguous identical matching of eight amino acids in AllergenOnline, version 18B.

\begin{tabular}{|c|c|c|c|c|c|}
\hline Allergen & Species & Description & $\begin{array}{l}\text { Sequence in } \\
\text { FARRP * }\end{array}$ & $\begin{array}{l}\text { Sequence } \\
\text { Length }\end{array}$ & $\begin{array}{c}\text { Matching Region of } \\
\text { Contiguous Amino Acids }\end{array}$ \\
\hline Chitinase & Zea mays L. & Food allergen & GI:260401081 & 279 & 62_GGGGGGGG-69 \\
\hline Endochitinase A & Zea mays L. & Food allergen & GI:116329 & 281 & 61_GGGGGGGG-68 \\
\hline
\end{tabular}

* Food Allergy Research and Resource Program (FARRP).

\subsection{Thermal Stability Assessment}

Transgenic sugarcane has been previously confirmed by PCR DNA amplification to yield a 550-bp fragment of the nptII gene, and the transgenic plants were designated SP1, SP2, SP3, and SP4 (Figure S2). An extracted protein sample from transgenic sugarcane was prepared for heat stability testing, the 
protein profile was determined by Western blot analysis (Figure 1A) and monitored with an enzymatic activity assay (Figure 1B). The SPS protein at time zero in the control sample was clearly detected with the major band at $120 \mathrm{kDa}$ by Western blot analysis. When the samples were treated at $28^{\circ} \mathrm{C}, 60^{\circ} \mathrm{C}$, and $90^{\circ} \mathrm{C}$ for up to $10 \mathrm{~min}$, the major band of the SPS protein $(120 \mathrm{kDa})$ was still detected (Figure $\left.1 \mathrm{~A}\right)$. However, the SPS activity assay result showed a gradual decrease during the time-course of incubation despite the fact that the protein remained detectable. The activity of SPS was reduced after $5 \mathrm{~min}$ of incubation at room temperature $\left(28^{\circ} \mathrm{C}\right)$, while the enzyme was inactivated thoroughly by incubating the enzyme at $60^{\circ} \mathrm{C}$ and $90^{\circ} \mathrm{C}$ for $5 \mathrm{~min}$ (Figure 1B).

(A)

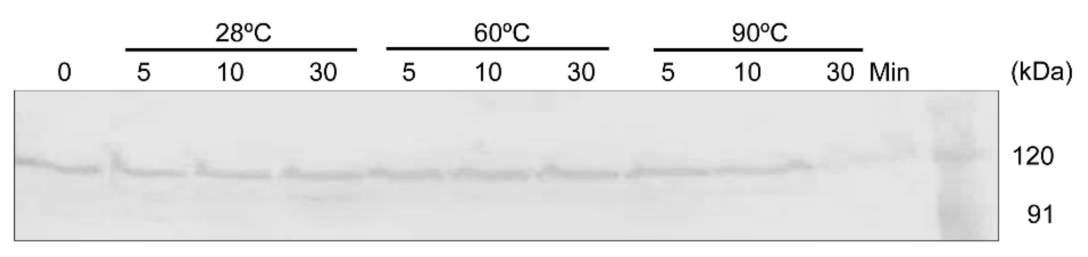

(B)
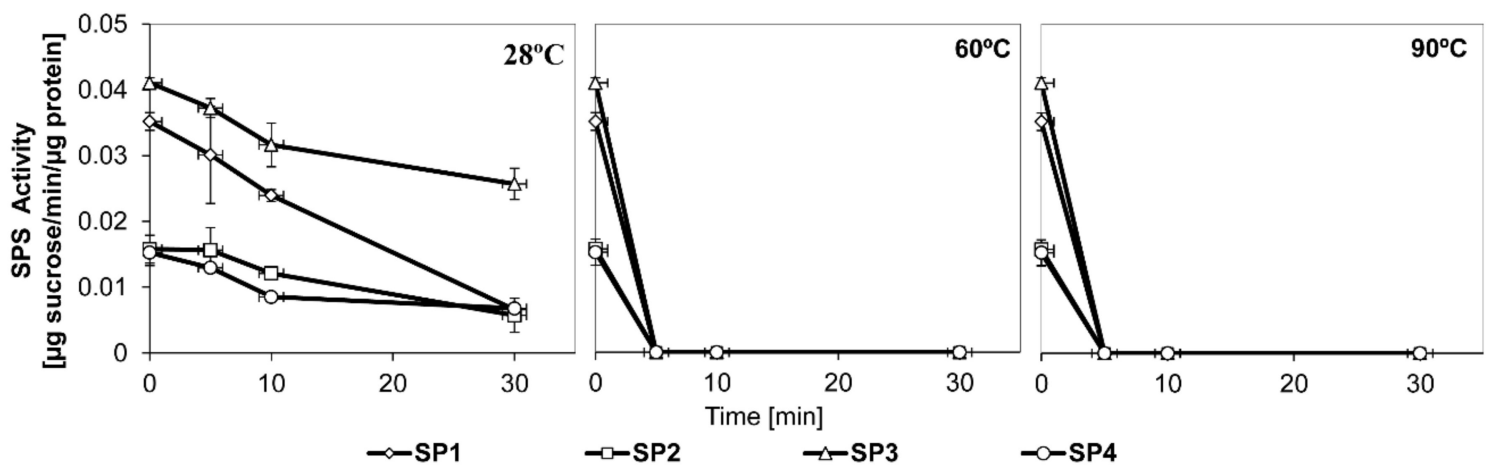

Figure 1. Heat stability of sucrose-phosphate synthase (SPS) protein extracted from leaves of transgenic sugarcane. The crude extract protein of transgenic sugarcane was subjected to heat treatment at indicated temperature for periods of $0,5,10$, and $30 \mathrm{~min}$. As a control, the extract protein was not subjected to any heat treatment $(0 \mathrm{~min})$. The level of SPS protein was monitored by Western blotting and the SPS was comparable in size with the molecular mass marker at $120 \mathrm{kDa}$ (A). The activity level of SPS was measured using spectrophotometer at $520 \mathrm{~nm}$ before and after a heat treatment (B).

Transgenic crops may contain new expressed proteins that require safety assessment procedures to evaluate protein stability [38]. Proteins with high stability in elevated temperature are generally associated with allergenic potential [3,39]. Identification of potential protein hazards can be conducted by examining physical properties through a heating stability assessment [38]. We assume that SPS protein was susceptible to heat treatment [40]. In fact, SPS protein was still detected at the highest temperature $\left(90^{\circ} \mathrm{C}\right)$ of incubation (Figure 1A). The additional test of enzymatic activity analysis under heat treatment is required to prove the protein stability and function of SPS. The enzymatic activity of SPS showed that the activity of SPS gradually declined at the temperature of $28{ }^{\circ} \mathrm{C}$ and completely lost at $60^{\circ} \mathrm{C}$ and $90^{\circ} \mathrm{C}$ for 5 min incubation. The loss of enzymatic activity suggested that SPSs might be denatured and lose their function. In order to verify the protein stability assessment, the enzyme activity measurement was conducted to consider and interpret potential allergenicity.

A similar result was obtained in the safety assessment for transgenic plant-expressed phosphinothricin acetyltransferase (PAT). Although no protein degradation was shown on SDS-PAGE after heat treatment at $90^{\circ} \mathrm{C}$, the PAT protein was completely inactivated [41,42]. The results of PAT protein analysis corroborated our heat stability results. By analogy, it revealed that SPS lost its catalytic functionality under denaturing conditions and had no potential to become an allergen. 


\subsection{In Vitro Simulated Gastric Fluids (SGF) and Simulated Intestine Fluid (SIF) Assessment}

The SGF and SIF models provide allergenic potential evaluation methods, since food proteins are rapidly digested by gastric and intestinal processes $[3,43]$. The combined results of CBB-stained SDS-PAGE gels and Western blotting showed that transgenic sugarcane protein, at time zero as a control sample, underwent no significant degradation changes in the absence of pepsin and trypsin (Figure 2A,B, upper and middle).

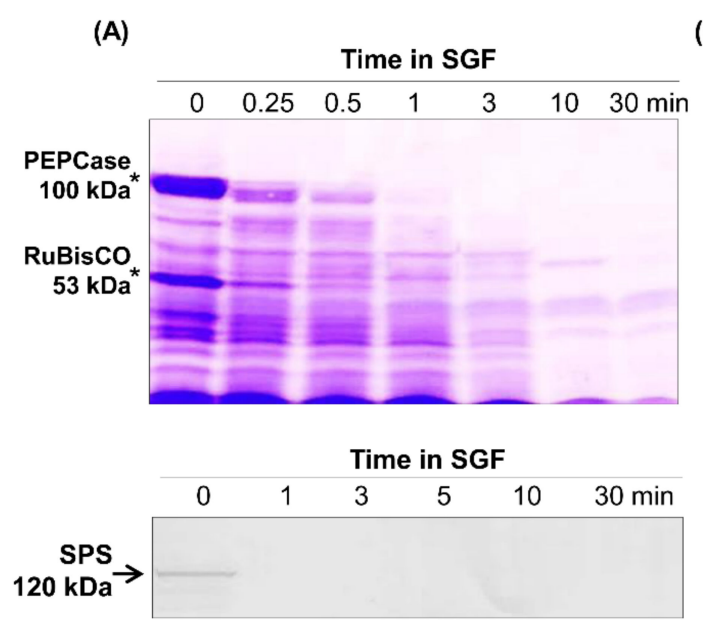

(B)
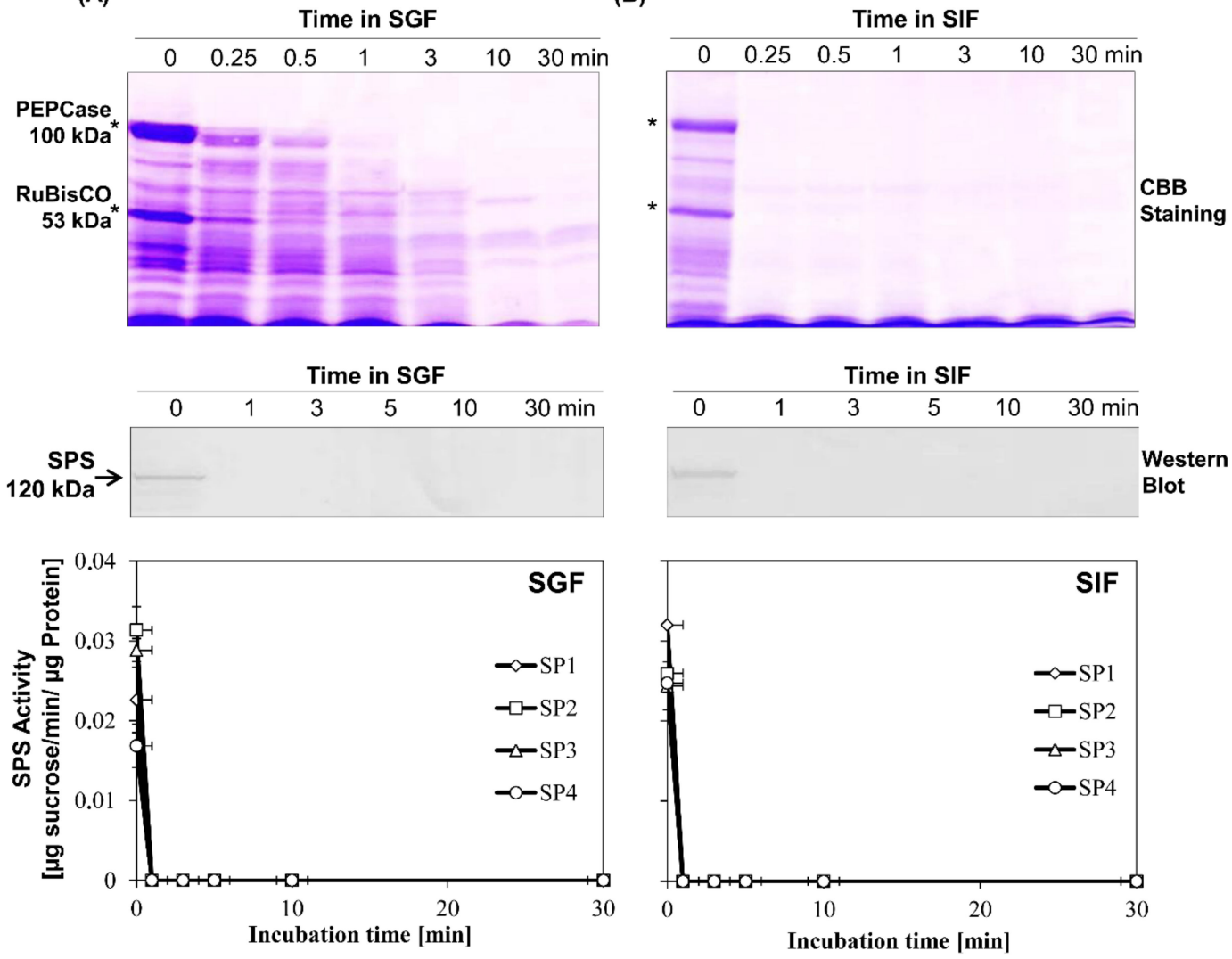

Figure 2. In vitro simulated gastric fluids (SGF) and simulated intestine fluid (SIF) digestion assays of SPS protein. The extracted protein from transgenic sugarcane was digested by pepsin in SGF (A) and trypsin in SIF (B). The profile of protein after digestive treatment at indicated times were analyzed by SDS-PAGE, followed by staining with Coomassie Brilliant Blue (upper) and subjected to Western blotting using a polyclonal antibody against SPS (middle). The activity of SPS was measured in the extracted protein at incubation times of $0,1,3,5,10$, and $30 \mathrm{~min}$ after digestion (lower). Upper and lower asterik represent PEPCase and RubisCO protein bands, respectively. Arrow represents SPS protein band.

However, as shown by the CBB protein staining, almost all of the crude protein in the transgenic sugarcane exhibited changes in the digestion pattern over a few minutes of incubation, and was thoroughly digested during the duration of the $30 \mathrm{~min}$ treatment (Figure 2A,B, upper). The crude proteins were gradually degraded within 0.25 to $0.5 \mathrm{~min}$ through treatment with pepsin and trypsin and remarkably lost after $1 \mathrm{~min}$ of incubation. Moreover, the major protein bands that consisted of C4 plant endogenous PEP carboxylase and the large subunit of Rubisco, with molecular masses of approximately $100 \mathrm{kDa}$ and $53 \mathrm{kDa}$, respectively, were susceptible to degradation in the SGF and SIF assessments.

Western blot analysis showed that the SPS protein was completely digested in 1 min by SGF and SIF assessments (Figure 2A,B, middle). The result of the activity assay was also in good agreement with the protein profiles from Western blot analysis. The loss of enzymatic activity was shown after $1 \mathrm{~min}$ 
incubation of the digestive enzymes, that indicated the SPS activity is rapidly inactivated (Figure 2A,B, lower). Collectively, the results showed that SPS and other proteins in transgenic sugarcane can be degraded by the enzymatic digestion system.

Proteins that are rapidly degraded into small peptides and amino acids can be considered less allergenic since the protein is not able to resist the acidic conditions of the digestive system [3,39]. Regarding the in vitro digestibility, our result has good relevance in regard to the efficiency of enzymatic digestion in the stomach and intestine.

\subsection{In Vivo Allergenicity Assay in Rats and Measurement of the Protein-Specific IgE Antibody}

Typical allergy symptoms are usually triggered by the production of immunoglobulin E (IgE) [32,44]. In this work, rats were used as an animal model to examine the accumulation of $\operatorname{IgE}[16,45]$ after sensitization to non-transgenic and transgenic sugarcane juice. The treatment was devided into four groups, with three replicates in each group. The treatment group consists of $\mathrm{C}-$ is not subjected to any treatment as a negative control, WT is subjected to non-transgenic sugarcane juice, SP is subjected to transgenic sugarcane juice, and $\mathrm{C}+$ is OVA sensitization as a positive control.

The specific-IgE levels in sera between the non-transgenic and transgenic sugarcane groups were compared to interpret the potential allergenicity of the transgenic crops. The antibody titers at day 7 and day 14 were observed to evaluate the accumulation of IgE in sera. The production of antibodies at day 7 was lower in titer and appeared similar among samples from the $\mathrm{C}-$, WT, SP, and C+ groups (Figure 3). Statistical analysis showed that there is no significant difference $(p>0.05)$ between the $\mathrm{C}-$, WT, SP, and C+ samples at day 7. Synthesis of allergen-specific IgE generally occurred at approximately 7 days, and the peak of the IgE titer was produced during days 10 to 14; thus, a booster injection was required to stimulate increased levels of $\operatorname{IgE}[45,46]$. Continuous ingestion of OVA showed a significant increase in the IgE level at day 14, which was higher by almost four-fold than IgE production at day 7 (Figure 3). Statistical analysis showed a significant difference $(p<0.05)$ between rats fed OVA and those fed transgenic sugarcane juice. However, the IgE titers of $C$ - and SP samples at day 14 were shown to be comparable with the IgE titers at day 7. Moreover, the declined antibody titers of the WT group samples at day 14 suggested the degradation of antigens. Based on the animal model experiments, the results of the specific-IgE assessment indicated that transgenic sugarcane juice has no potential to be allergenic.

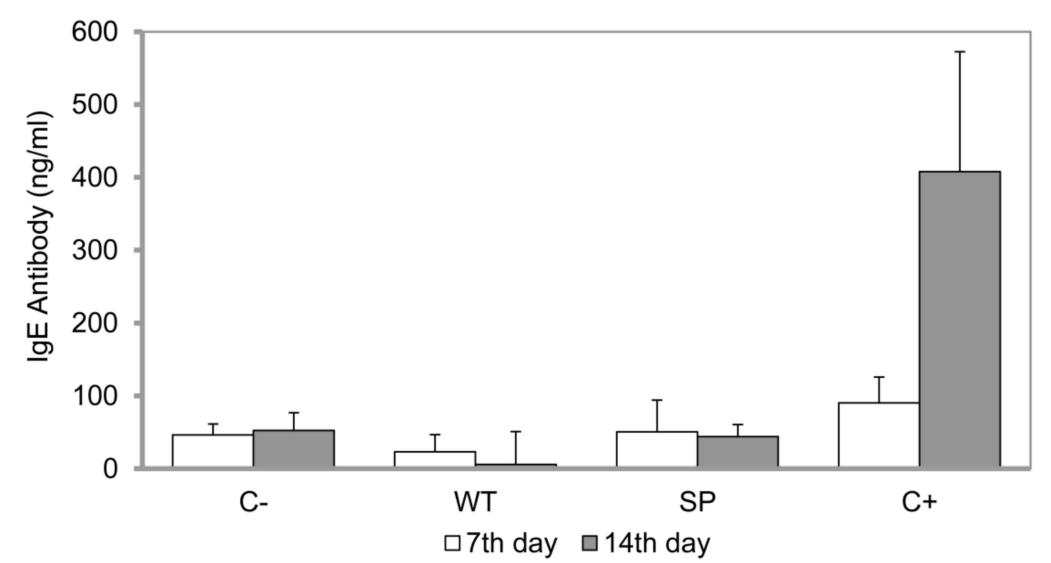

Figure 3. Quantitative analysis of the IgE antibody levels using ELISA for allergenicity assessment. The rats ( $n=3$ /group) were sensitized with transgenic (SP) and non-transgenic (WT) sugarcane juice, and the accumulations of IgE antibody titers in rat serum were determined by ELISA at 7th and 14th day, thereafter. The IgE antibody levels were presented as means $\pm \mathrm{SEM}$ (standard error mean). The serum of no treatment rat $(\mathrm{C}-)$ and OVA-sensitized rat $(\mathrm{C}+)$ were also analyzed to compare the $\operatorname{IgE}$ antibody levels of WT and SP. 


\subsection{Acute Oral Toxicity Assessment}

The acute oral toxicity was assessed as described in the general principles of Guidelines for the Testing of Chemicals by Organization for Economic Co-operation and Development (OECD) guideline 420 with appropriate modification [3]. The toxicity assessment showed that the mice appeared healthy throughout the treatments until sacrifice on day 14. The signs of toxicity such as piloerection, motor activity, vocal tremor, and feces were not observed during observation.

The toxicity study showed that animal death was not occured at any of sugarcane juice dose treatments $(6.25,12.5$, and $25 \mathrm{gr} / \mathrm{kg}$ of body weight) (Table 2). In addition, similar results were also observed in the control mice administered with $0.5 \%$ of CMC-Na solution. These results revealed that transgenic sugarcane is considered non-toxic since the mortality rates remained zero after treatment with the highest tested dose of sugarcane juice at $25 \mathrm{gr} / \mathrm{kg}$ body weight.

Table 2. Acute toxicity study in mice.

\begin{tabular}{cccccc}
\hline \multirow{2}{*}{ Group Treatment } & \multirow{2}{*}{ Sample Treatment } & Dosage (gr/kg) & \multicolumn{3}{c}{ Death of Animals } \\
\cline { 4 - 6 } & & After 72 h & After 14 Days & Percentage (\%) * \\
\hline I & Control & 0 & 0 & 0 & 0 \\
II & Sugarcane Juice & 6.25 & 0 & 0 & 0 \\
II & Sugarcane Juice & 12.5 & 0 & 0 & 0 \\
IV & Sugarcane Juice & 25 & 0 & 0 & 0 \\
\hline
\end{tabular}

* The mortality percentage in mice ( $n=10$ /group); Death of animals after 14 days was zero percent, thus the Lethal Dose $50\left(\mathrm{LD}_{50}\right)>25 \mathrm{gr} / \mathrm{kg}$.

The body weight of mice was measured daily for 14 days, and the recorded data was plotted on a graph (Figure 4). The result showed that there were slight gains in body weight at the doses of $6.25,12.5$, and $25 \mathrm{gr} / \mathrm{kg}$ body weight. The body weight gain was a reflection of the normal pattern of body weight growth, since a similar growth pattern was observed in the mice treated with the control CMC-Na solution. Statistical analysis showed that there was no significant difference $(p>0.05)$ in regard to the gain in body weight between sugarcane juice treatments and the control. Thus, all treated mice had similar body weight in both groups during 14 days of observation.

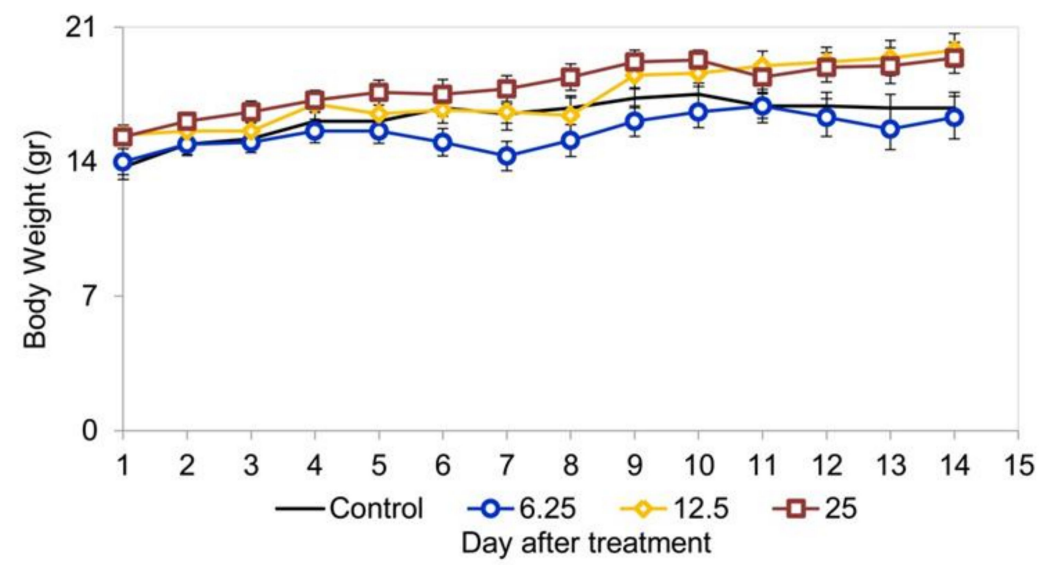

Figure 4. Graph of mice body weights after administration of transgenic sugarcane juice for toxicity assessment. The BALB/c mice ( $n=10$ /group) were administered transgenic sugarcane juice in a dosage-dependent manner $(0 ; 6.25 ; 12.5 ; 25 \mathrm{gr} / \mathrm{kg}$ of body weight), and the body weight of the mice were measured daily for 14 days. The body weight values are presented as the mean $\pm \mathrm{SEM}$ and showed no significant difference $(p>0.05)$ between groups.

To confirm the results from the toxicity assessment of sugarcane juice, the internal vital organs of the mice were dissected after sacrifice at day 14 and the wet weight was recorded. The wet weights of the organs showed no significant differences $(p>0.05)$ between the sugarcane juice and control 
treatments. The relative organs wet weight of heart, liver, spleen, and kidneys were also similar and not affected by sugarcane juice treatments (Table 3). In addition, macroscopic observation showed no changes in the organs. However, the microscopic observation was not conducted since the mice showed no abnormal tendency. These results imply that transgenic sugarcane juice has no toxicity effect in the mice. According to OECD guidelines, additional testing is not required since there was no mice death recorded in the toxicity assessment.

Table 3. Mice organ weight measurements for acute toxicity analysis.

\begin{tabular}{ccccc}
\hline \multirow{2}{*}{ Organs } & \multicolumn{4}{c}{ Dosage of Sugarcane Juice } \\
\cline { 2 - 5 } & $\mathbf{0 ~ g r / \mathbf { k g }}$ & $\mathbf{6 . 2 5} \mathbf{~ g r} / \mathbf{k g}$ & $\mathbf{1 2 . 5} \mathbf{~ g r} / \mathbf{k g}$ & $\mathbf{2 5} \mathbf{~ g r} / \mathbf{k g}$ \\
\hline Heart & $0.37 \pm 0.03$ & $0.44 \pm 0.03$ & $0.41 \pm 0.03$ & $0.44 \pm 0.04$ \\
Liver & $5.74 \pm 0.68$ & $6.25 \pm 0.19$ & $7.06 \pm 0.07$ & $6.80 \pm 0.10$ \\
Spleen & $0.77 \pm 0.17$ & $0.79 \pm 0.06$ & $0.85 \pm 0.02$ & $0.84 \pm 0.11$ \\
Kidneys & $1.31 \pm 0.10$ & $1.56 \pm 0.03$ & $1.29 \pm 0.07$ & $1.43 \pm 0.12$ \\
\hline
\end{tabular}

The weight values are the mean \pm SEM ( $n=5$ /group), with the mean of weight being wet organ (gr)/body weight (gr). The statistical result was $p>0.05$ (one-way ANOVA) for transgenic sugarcane juice treatment compared to the control.

\subsection{A Model for Food Safety Assessment of Transgenic Sugarcane}

The allergenicity evaluation consists of three steps: Bioinformatics analysis, in vitro thermal testing and digestive stability assessments, and in vivo IgE analysis in rats. These assessments were conducted according to the guidelines of the Codex Alimentarius Commission. Furthermore, toxicity testing was conducted by acute oral toxicity assays in mice with a procedure adopted from the OECD. Moreover, it has been documented that sugarcane has not been associated with an allergenic response, as there have been no reports regarding food-related allergic reactions to sugarcane [47]. Thus, we propose a model for the risk assessment framework in transgenic sugarcane as shown in Figure 5.

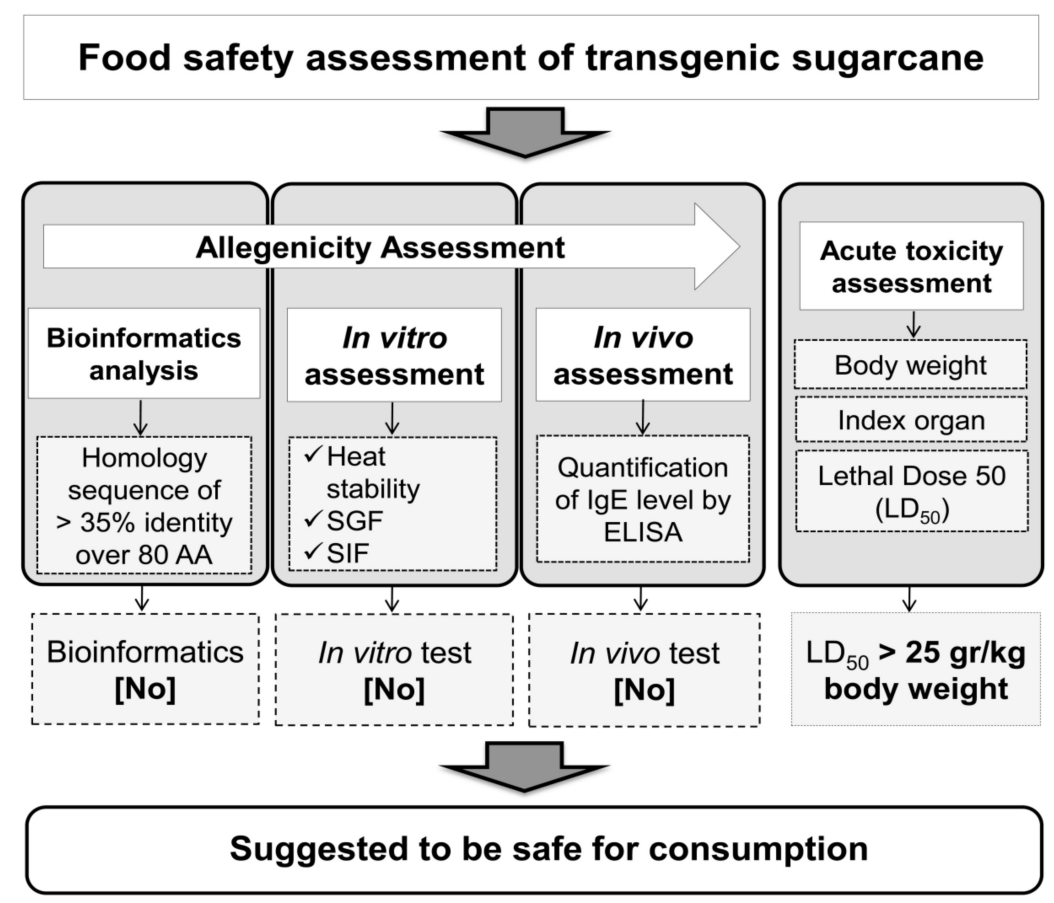

Figure 5. Overview and framework of food safety risk analysis in transgenic sugarcane. The food safety assessment of transgenic sugarcane consists of several steps including allergenicity and toxicity tests. The total protein was utilized for in vitro assessment, while animal models were used for in vivo assessment using sugarcane juice to compare the effects of administration of transgenic and non-transgenic sugarcanes. 


\section{Conclusions}

In this study, bioinformatics analysis showed no sequence homology with any allergens in segments over 80 amino acids in length. The SPS protein was rapidly degraded by the enzymatic digestive system and inactivated by heating treatment. There was also low production of IgE after sensitization to transgenic sugarcane. Additionally, no mortality occurred after treatment with the highest dose of $25 \mathrm{~g} / \mathrm{kg}$ juice of transgenic sugarcane. These results prove that the overexpressed SPS gene in transgenic sugarcane does not possess characteristics associated with allergens and is not toxic. Biochemical and molecular analysis provide new insight regarding the potential allergenicity and toxicity of transgenic sugarcane as well as other transgenic crops.

Supplementary Materials: The following are available online at http://www.mdpi.com/2073-4395/9/1/23/s1, Figure S1: The corresponding amino acid sequences of SoSPS1 (a). The result of a sliding 80 amino acids window for SoSPS1 obtained through the database of Allergen Online, version 18B (b), Figure S2: The positive transgenic sugarcane (SP1, SP2, SP3, SP4) and non-transgenic sugarcane (WT1 and WT2) genes were detected by PCR amplification.

Author Contributions: I.R.N, Formal analysis and Data curation; W.D.S, Formal analysis, Data curation, and Writing-original draft; N.E, Software, Data curation and Validation; T.H, Investigation, Methodology B.S, Conceptualization, Funding acquisition, Supervision and Writing-original draft.

Acknowledgments: This research was supported by a research grant (PUSNAS) from the Ministry of Research, Technology and Higher Education of the Republic of Indonesia.

Conflicts of Interest: Authors declare no conflict of interest.

\section{References}

1. FAO/WHO. Evaluation of Allergenicity of Genetically Modified Foods; Report of a Joint FAO/WHO Expert Consultation of Allergenicity of Foods Derived from Biotechnology: Rome, Italy, 2001.

2. Delaney, B. Safety assessment of foods from genetically modified crops in countries with developing economies. Food Chem. Toxicol. 2015, 86, 132-143. [CrossRef]

3. Farias, D.F.; Viana, M.P.; Oliveira, G.R.; Santos, V.O.; Pinto, C.E.M.; Viana, D.A.; Vasconcelos, I.M.; de-Sa, M.F.G.; Carvalho, A.F.U. Food safety assessment of Cry8Ka5 mutant protein using Cry1Ac as a control Bt protein. Food Chem. Toxicol. 2015, 81, 81-91. [CrossRef]

4. Zhao, K.; Ren, F.; Han, F.; Liu, Q.; Wu, G.; Xu, Y.; Zhang, J.; Wu, X.; Wang, J.; Li, P.; et al. Edible safety assessment of genetically modified rice T1C-1 for Sprague Dawley rats through horizontal gene transfer, allergenicity and intestinal microbiota. PLoS ONE 2016, 11, e0163352. [CrossRef] [PubMed]

5. Codex Alimentarius Commission. Joint FAO/WHO Food Standard Program, Food and Agriculture Organization of the United Nations; Food Derived from Biotechnology: Rome, Italy, 2003.

6. Parrott, W.; Chassy, B.; Ligon, J.; Meyer, L.; Petrick, J.; Zhou, J.; Herman, R.; Delaney, B.; Levine, M. Application of food and feed safety assessment principles to evaluate transgenic approaches to gene modulation in crops. Food Chem. Toxicol. 2010, 48, 1773-1790. [CrossRef] [PubMed]

7. Dunn, S.E.; Vicini, J.L.; Glenn, K.C.; Fleischer, D.M.; Greenhawt, M.J. The allergenicity of genetically modified foods from genetically engineered crops: A narrative and systematic review. Ann. Allergy Asthma Immunol. 2017, 119, 214-222. [CrossRef]

8. Lee, R.; Reiner, D.; Dekan, G.; Moore, A.E.; Epstein, M.M.; Higgins, T.J.V. Genetically modified $\alpha$-amylase inhibitor peas are not specifically allergenic in mice. PLoS ONE 2013, 8, e52972. [CrossRef]

9. Sugiharto, B. Biotechnology of drought-tolerant sugarcane. In Sugarcane Technology and Research; Olieveira, A.D., Ed.; InTech Open: London, UK, 2018; ISBN 978-1-78923-151-9.

10. Waltz, E. Beating the heat; Despite the complexity of drought tolerance, researcher is making progress in the search for crops that can produce seed with limited water. Nat. Biotechnol. 2014, 32, 610-613. [CrossRef]

11. Gao, S.; Yang, Y.; Wang, C.; Guo, J.; Zhou, D.; Wu, Q.; Su, Y.; Xu, L.; Que, Y. Transgenic sugarcane with a cry $1 A c$ gene exhibited better phenotypic traits and enhanced resistance against sugarcane borer. PLOS ONE 2016, 11, e0153929. [CrossRef] [PubMed] 
12. Wang, W.Z.; Yang, B.P.; Feng, X.Y.; Cao, Z.Y.; Feng, C.L.; Wang, J.G.; Xiong, G.R.; Shen, L.B.; Zeng, J.; Zhao, T.T.; et al. Development and characterization of transgenic sugarcane with insect resistance and herbicide tolerance. Front. Plant Sci. 2017, 8, 1-10. [CrossRef]

13. Yao, W.; Ruan, M.; Qin, L.; Yang, C.; Chen, R.; Chen, B.; Zhang, M. Field performance of transgenic sugarcane lines resistant to sugarcane mosaic virus. Front. Plant Sci. 2017, 8, 104. [CrossRef]

14. Apriasti, R.; Widyaningrum, S.; Hidayati, W.N.; Sawitri, W.D.; Darsono, N.; Hase, T.; Sugiharto, B. Full sequence of the coat protein gene is required for the induction of pathogen-derived resistance against sugarcane mosaic virus in transgenic sugarcane. Mol. Biol. Rep. 2018, 45, 2749-2758. [CrossRef] [PubMed]

15. Astwood, J.D.; Leach, J.N.; Fuchs, R.L. Stability of food allergens to digestion in vitro. Nat. Biotechnol. 1996, 14, 1269-1273. [CrossRef] [PubMed]

16. Knippels, L.M.; Penninks, A.H.; Smit, J.J.; Houben, G.F. Immune-mediated effects upon oral challenge of ovalbumin-sensitized Brown Norway rats: Further characterization of a rat food allergy model. Toxicol. Appl. Pharmacol. 1999, 156, 161-169. [CrossRef]

17. Domingo, J.L. Toxicity studies of genetically modified plants: A review of the published literature. Crit. Rev. Food Sci. Nutr. 2007, 47, 721-733. [CrossRef] [PubMed]

18. Fares, N.H.; El-Sayed, A.K. Fine structural changes in the ileum of mice fed on delta-endotoxin-treated potatoes and transgenic potatoes. Nat. Toxins 1998, 6, 219-233. [CrossRef]

19. Delaney, B.; Astwood, J.D.; Cunny, H.; Conn, R.E.; Herouet-Guicheney, C.; Macintosh, S.; Meyer, L.S.; Privalle, L.; Gao, Y.; Mattsson, J.; et al. Evaluation of protein safety in the context of agricultural biotechnology. Food Chem. Toxicol. 2008, 46, S71-S97. [CrossRef] [PubMed]

20. Gad, S.C. Chapter 2-Rodents model for toxicity testing and biomarkers. In Biomarkers in Toxicology; Gupta, R.C., Ed.; Academic Press: Cambridge, UK, 2014; pp. 8-68, ISBN 978-0-12-404630-6.

21. OECD. Acute Oral Toxicity-Fixed Dose Procedure Section 4. In OECD Guideline for the Testing of Chemicals No 420; OECD Publishing: Paris, France, 2001; pp. 1-14.

22. Song, Y.; Liang, C.; Wang, W.; Fang, J.; Sun, N.; Jia, X.; Li, N. Immunotoxicological evaluation of corn genetically modified with Bacillus thuringiensis Cry1Ah gene by a 30-day feeding study in BALB/c mice. PLoS ONE 2014, 9, e78566. [CrossRef]

23. Sugiharto, B.; Sakakibara, H.; Sumadi; Sugiyama, T. Differential expression of two genes for sucrose-phosphate synthase in sugarcane: Molecular cloning of the cDNAs and comparative analysis of gene expression. Plant Cell Physiol. 1997, 38, 961-965. [CrossRef] [PubMed]

24. Sawitri, W.D.; Narita, H.; Ishizaka-Ikeda, E.; Sugiharto, B.; Hase, T.; Nakagawa, A. Purification and characterization of recombinant sugarcane sucrose phosphate synthase expressed in E. coli and insect Sf9 cells: An importance of the N-terminal domain for an allosteric regulatory property. J. Biochem. 2016, 159, 599-607. [CrossRef] [PubMed]

25. Goodman, R.E.; Ebisawa, M.; Ferreira, F.; Sampson, H.A.; Van Ree, R.; Vieths, S.; Baumert, J.L.; Bohle, B.; Lalithambika, S.; Wise, J.; et al. AllergenOnline: A peer reviewed, curated allergen database to assess novel food proteins for potential cross-reactivity. Mol. Nutr. Food Res. 2016, 60, 1183-1198. [CrossRef] [PubMed]

26. Bradford, M.M. A rapid and sensitive method for the quantitation of microgram quantities of protein utilizing the principle of protein-dye binding. Anal. Biochem. 1976, 72, 248-254. [CrossRef]

27. Roesler, K.R.; Rao, A.G. Rapid gastric fluid digestion and biochemical characterization of engineered proteins enriched in essential amino acids. J. Agric. Food Chem. 2001, 49, 3443-3451. [CrossRef] [PubMed]

28. Laemmli, U.K. Cleavage of structural proteins during the assembly of the head of bacteriophage T4. Nature 1970, 227, 680-685. [CrossRef]

29. Bellou, A.; Saint-Laudy, J.; Knippels, L.; Montemont, C.; Vauthier, E.; Gerard, P.; Pellegrom, H.; Koerkamp, E.K.; Lesesve, J.F.; Gueant, J.L.; et al. Brown Norway rat ovalbumin-specific immunoglobulin E antibodies increase the human basophil expression of CD63 marker. Scand. J. Immunol. 2002, 57, $271-278$. [CrossRef]

30. Verma, S.K.; Srikanth, R.; Das, SK.; Venkidachalam, G. An efficient and novel approach for clarification of sugarcane juice by micro- and ultrafiltration methods. Indian J. Chem. 1996, 3, 136-139.

31. Shi, W.; Zhang, C.; Zhao, D.; Wang, L.; Li, P.; Li, H. Discovery of hepatotoxic equivalent combinatorial markers from Dioscorea bulbifera tuber by fingerprint-toxicity relationship modeling. Sci. Rep. 2018, 8, 1-11. [CrossRef] [PubMed] 
32. Ladics, G.S.; Cressman, R.F.; Herouet-Guicheney, C.; Herman, R.A.; Privalle, L.; Song, P.; Ward, J.M.; McClain, S. Bioinformatics and the allergy assessment of agricultural biotechnology products: Industry practices and recommendations. Regul. Toxicol. Pharmacol. 2011, 60, 46-53. [CrossRef] [PubMed]

33. Young, G.J.; Zhang, S.; Mirsky, H.P.; Cressman, R.F.; Cong, B.; Ladics, G.S.; Zhong, C.X. Assessment of possible allergenicity of hypothetical ORFs in common food crops using current bioinformatic guidelines and its implications for the safety assessment of GM crops. Food Chem. Toxicol. 2012, 50, 3741-3751. [CrossRef]

34. Goodman, R.E.; Vieths, S.; Sampson, H.A.; Hill, D.; Ebisawa, M.; Taylor, S.L.; van Ree, R. Allergenicity assessment of genetically modified crops-what makes sense? Nat. Biotechnol. 2008, 26, 73-81. [CrossRef]

35. Herman, R.A.; Song, P.; Sekhar, A.R. Value of eight-amino-acid matches in predicting the allergenicity status of protein: An empirical bioinformatics investigation. Clin. Mol. Allergy 2009, 7, 1-7. [CrossRef]

36. Goodman, R.E.; Tetteh, A.O. Suggested improvements for the allergenicity assessment of genetically modified plants used in foods. Curr. Allergy Asthma Rep. 2011, 11, 317-324. [CrossRef] [PubMed]

37. Jin, Y.; Goodman, R.E.; Tetteh, A.O.; Lu, M.; Tripathi, L. Bioinformatics analysis to assess potential risks of allergenicity and toxicity of HRAP and PFLP proteins in genetically modified bananas resistant to Xanthomonas wilt disease. Food Chem. Toxicol. 2017, 109, 81-89. [CrossRef]

38. Bushey, D.F.; Bannon, G.A.; Delaney, B.F.; Graser, G.; Hefford, M.; Jiang, X.; Lee, T.C.; Madduri, K.M.; Pariza, M.; Privalle, L.S.; et al. Characteristics and safety assessment of intractable proteins in genetically modified crops. Regul. Toxicol. Pharmacol. 2014, 69, 154-170. [CrossRef] [PubMed]

39. Xu, W.; Cao, S.; He, X.; Luo, Y.; Guo, X.; Yuan, Y.; Huang, K. Safety assessment of Cry1Ab/Ac fusion protein. Food Chem. Toxicol. 2009, 47, 1459-1465. [CrossRef] [PubMed]

40. Huber, S.C.; Huber, J.L. Role of sucrose-phosphate synthase in sucrose metabolism in leaves. Plant Physiol. 1992, 99, 1275-1278. [CrossRef] [PubMed]

41. Herouet, C.; Esdaile, D.J.; Mallyon, B.A.; Debruyne, E.; Schulz, A.; Currier, T.; Hendrickx, K.; van der Klis, R.J.; Rouan, D. Safety evaluation of the phosphinothricin acetyltransferase proteins encoded by the pat and bar sequences that confer tolerance to glufosinate-ammonium herbicide in transgenic plants. Regul. Toxicol. Pharmacol. 2005, 41, 134-149. [CrossRef] [PubMed]

42. Wehrmann, A.; Van Vliet, A.; Opsomer, C.; Botterman, J.; Schulz, A. The similarities of bar and pat gene products make them equally applicable for plant engineers. Nat. Biotechnol. 1996, 14, 1274-1278. [CrossRef] [PubMed]

43. Mathur, C.; Kathuria, P.C.; Dahiya, P.; Singh, A.B. Lack of detectable allergenicity in genetically modified maize containing "Cry" proteins as compared to native maize based on in silico \& in vitro analysis. PLoS ONE 2015, 10, e0117340. [CrossRef]

44. Menezes, S.P.; Santos, J.L.; Cardoso, T.H.S.; Pirovani, C.P.; Micheli, F.; Noronha, F.S.M.; Alves, A.C.; Faria, A.M.C.; Gesteira, A.S. Evaluation of the allergenicity potential of TcPR-10 protein from Theobromo cacao. PLoS ONE 2012, 7, e37969. [CrossRef]

45. Fritsche, R. Animal models in food allergy: Assessment of allergenicity and preventive activity of infant formulas. Toxicol. Lett. 2003, 140-141, 303-309. [CrossRef]

46. Adkinson, N.F.; Bochner, B.S.; Busse, W.W.; Holgate, S.T.; Lemanske, R.F.; Simons, F.E.R. Middleton's Allergy Principles and Practice, 7th ed.; Elsevier: Philadelphia, PA, USA, 2009; p. 440. ISBN 978-0-323-04884-2.

47. OECD. Novel Food and Feed Safety: Safety Assessment of Foods and Feeds Derived from Transgenic Crops; OECD Publishing: Paris, France, 2015; pp. 174-179. ISBN 978-92-64-18033-8.

(C) 2019 by the authors. Licensee MDPI, Basel, Switzerland. This article is an open access article distributed under the terms and conditions of the Creative Commons Attribution (CC BY) license (http://creativecommons.org/licenses/by/4.0/). 